Дунська А. P.

канд. економ. наук, доцент

Бойко О. В.

Національний технічний університет Украӥни «КПІ», м. Київ

\title{
ПРЯМІ ІНОЗЕМНІ ІНВЕСТИЩІЇ ЯК ЧИННИК РОЗВИТКУ ЕКОНОМІКИ УКРАЇНИ
}

\section{ПРЯМЫЕ ИНОСТРАННЫЕ ИНВЕСТИЦИИ КАК ФАКТОР РАЗВИТИЯ ЭКОНОМИКИ УКРАИНЫ}

\section{FOREIGN DIRECT INVESTMENTS AS A FACTOR OF ECONOMIC DEVELOPMENT UKRAINE}

У статті розглянуто сутність поняття «прямі іноземні інвестиції» як економічної категорії. Виявлено взаємозв'язок досліджуваної категорії з макроекономічними показниками України. Проаналізовано динаміку, тендениії іноземних надходжень та основні країни-інвестори. Розглянуто галузеву та регіональну структуру прямих іноземних інвестицій. Здійснено дослідження інвестиційного клімату Украйни, иляхом порівняння позииій країни у міжнародних рейтингах та виявлено причини зниження очінок інвестиційного клімату Украӥни. Визначено проблеми, які стримують розвиток інвестииійної діяльності й знижують конкурентоспроможність економіки України на світовому ринку. Розглянуто основні позитивні кроки уряду у напрямку створення якісно нових умов ведення бізнесу та активізації інвестиційної діяльності. Запропоновано заходи щцодо стимулювання притоку прямих іноземних інвестицій, використання яких в перспективі призведе до усунення негативних тенденцій, стабілізації та розвитку економіки України.

Ключові слова: прямі іноземні інвестиції, інвестиційний клімат, економічний розвиток.

В данной статье исследованаа сущность понятия «прямые иностранные инвестиции» как экономической категории. Выявлена взаимосвязь исследуемой категории с макроэкономическими показателями Украины. Проанализирована динамика, тенденции иностранных поступлений и основные страны-инвесторы. Рассмотрены отраслевая и региональная структуры прямых иностранных инвестиций. Проведено исследование инвестиционного климата Украины, путем сравнения позиций страны в международных рейтингах и выявлены причины снижения оценок инвестиционного климата Украины. Определень проблемы, которые сдерживают развитие инвестиционной деятельности и снижают конкурентоспособность экономики Украины на мировом рынке. Рассмотрень основные положительные шаги правительства в направлении создания качественно новых условий ведения бизнеса и активизации инвестиционной деятельности. Предложены меры по стимулированию притока прямых иностранных инвестиций, использование которых в перспективе приведет к устранению негативных тендениий, стабилизаџии и развития экономики Украины.

Ключевые слова: прямые иностранные инвестиции, инвестиционный климат, экономическое развитие. 
This article deals with the essence of the concept of "foreign direct investment» as an economic category. The interrelation studied category of macroeconomic indicators. Analysed dynamics and trends of foreign revenue, examined the main investor countries. Considered the sectoral and regional structure of foreign direct investment. The investigation of the investment climate in Ukraine, by comparing the position of the country in international rankings and ratings revealed the reasons for reducing the investment climate in Ukraine. Detected problems that hinder the development of investment and reduce the competitiveness of Ukraine's economy in the global market. The main positive steps of the government towards the creation of a new business environment and stimulate investment. The measures to stimulate foreign direct use of which in the future will lead to the elimination of negative trends, stabilization and economic development of Ukraine.

Keywords: FDI, investment climate, economic development.

Вступ. В умовах динамічних змін зовнішнього середовища вітчизняна економіка переживає період кризи, державі складно забезпечити соціальноекономічний розвиток за рахунок власних фінансових ресурсів, що обумовлює потребу у активному залученні іноземного капіталу. Прямі іноземні інвестиції виступають стимулятором економічного розвитку та стабілізації політичної ситуації в країні. Актуальність досліджуваної тематики обумовлена тим, що підвищення інвестиційної привабливості України є одним із стратегічних завдань держави, від реалізації якого залежить можливість стабілізації та зростання національної економіки.

Питанням залучення іноземного капіталу в економіку України присвячені праці таких вчених: Кадеєва М. І. [1], Коваленко О. В. [2], Кудрик Г. П. [3], Леус М. М. [4], Реверчук С. К. [5], Рогач О. І. [6], Петренко І. С. [7], Тесля I. В. [8] та ін. Проте нині постає необхідність аналізу сучасних тенденцій прямих іноземних інвестицій в економіку нашої країни, визначення чинників їх впливу на рівень інвестиційного клімату та перспектив активізації інвестиційного процесу в державі, визначення іноземного інвестування як чинника стабілізації та розвитку вітчизняної економіки, підвищення іiі конкурентоспроможності на світовому ринку.

Постановка завдання. Метою статті $є$ дослідження сутності прямих іноземних інвестицій як чиннику розвитку економіки країни, здійснення оцінки надходження та розподілу іноземних інвестицій, аналізу динаміки іноземного інвестування у національну економіку. Ключовим завданням дослідження $\epsilon$ формування пропозицій щодо стимулювання іноземного інвестування та створення умов для подальшого збільшення обсягів залучення іноземних інвестицій.

Методологія дослідження формується на основі використання методів та прийомів наукового пізнання, таких як діалектична логіка, методи узагальнення та систематизації, методи системного та критичного аналізу, економіко-статистичні методи. 
Результати дослідження. Інтенсивний перехід до конкурентоспроможної моделі національної економіки зумовлює потребу співробітництва зі світовою системою господарювання, у якій іноземні інвестиції $\epsilon$ важливим економічним важелем. Створення відкритої, орієнтованої на експорт моделі економіки України значною мірою залежить від рівня активності іноземних інвесторів, інтенсивності міжнародного руху капіталів та поділу праці. Досліджуючи сутність прямих іноземних інвестицій, слід розглянути сучасні економічні підходи щодо їх трактування (табл. 1).

Таблиця 1

Підходи до трактування поняття «прямі іноземні інвестиції»

\begin{tabular}{|c|l|}
\hline Автор & \multicolumn{1}{|c|}{ Визначення поняття «прямі іноземні інвестиції» } \\
\hline $\begin{array}{c}\text { Закон України «Про } \\
\text { режим іноземного } \\
\text { інвестування» [9] }\end{array}$ & $\begin{array}{l}\text { Це всі види цінностей, що вкладаються іноземними інвесторами } \\
\text { в об'єкти інвестиційної діяльності. }\end{array}$ \\
\hline МВФ та ОЕСР [5, с. 20] & $\begin{array}{l}\text { Інвестиції, що здійснюються за межами національних кордонів } 3 \\
\text { метою розширення виробництва товарів і послуг, закупівлі } \\
\text { товарів для імпорту в країну базування або експорту в треті } \\
\text { країни. }\end{array}$ \\
\hline С. Хаймер [10] & $\begin{array}{l}\text { Це термін, що описує операцію отримання за кордоном фізичних } \\
\text { активів, за якої поточний контроль залишається у } \\
\text { багатонаціональної компанії у неї на батьківщині, тобто } \\
\text { контроль -цеключовий елемент ПІІ. }\end{array}$ \\
\hline СОТ [11] & $\begin{array}{l}\text { Такий вид інвестицій, за якого інвестор-резидент однієї країни } \\
\text { (країни-господаря), розміщує свої активи в межах іншої країни } \\
\text { (країна-реципієнті) за умови отримання контролю за цими } \\
\text { активами. }\end{array}$ \\
\hline С. Тесля [8] & $\begin{array}{l}\text { Це матеріальні і нематеріальні капітали, які вкладають держава, } \\
\text { компанія чи підприємець в інші підприємства за кордоном для } \\
\text { отримання підприємницького прибутку. }\end{array}$ \\
\hline
\end{tabular}

На основі розглянутих підходів до трактування поняття «прямі іноземні інвестиції» (табл. 1), сформовано наступне визначення досліджуваної категорії- це реальні вкладення капіталу за кордоном в підприємства, технологію, обладнання, землю, що забезпечує набуття довгострокового економічного інтересу через отримання інвестором контролю над об'єктом вкладення капіталу й передбачає одержання підприємницького прибутку або соціального ефекту.

Світова практика переконує, що без активного залучення іноземного капіталу неможливо провести структурну перебудову економіки, скоротити технологічну відсталість народного господарства та забезпечити конкурентоздатність вітчизняної продукції на світовому ринку. Тобто прямі іноземні інвестиції $є$ одним із чинників, які забезпечують економічне 
зростання та розвиток країни в цілому. Надходження іноземного капіталу зумовлює такі позитивні макроекономічні зрушення [1, с. 196; 12, с. 13]:

- посилення конкуренції між виробниками, за рахунок чого зростає ефективність виробництва та виробничі потужності країни;

- трансфер сучасних технологій та модернізація економіки на більш високому техніко-технологічному рівні;

- розвиток експортного потенціалу та просування українського товаровиробника на міжнародні ринки за рахунок досвіду роботи на них іноземних інвесторів;

- покращення платіжного балансу за рахунок збільшення обсягів бюджетних асигнувань у вигляді податків, які сплачують іноземні інвестори;

- активізація процесів інтеграції України в міжнародний бізнес за рахунок створення стратегічних альянсів між українськими та іноземними підприємствами.

Таким чином, іноземні інвестиції приносять не лише прибуток інвестору, а розширення міжнародного співробітництва та соціальний ефект країні у вигляді зростання доходів населення, що призводить до активізації платоспроможного попиту та забезпечує ланцюгову реакцію позитивних змін в національній економіці. Для комплексної оцінки впливу іноземного інвестування на економіку України проаналізуємо динаміку їх надходжень та основних країн-інвесторів за останні п’ять років (табл. 2).

Таблиця 2

Прямі іноземні інвестиції в Україну за 2010-2014 pp.

\begin{tabular}{|c|c|c|c|c|c|c|c|c|c|c|c|}
\hline \multirow{3}{*}{ Країна } & \multicolumn{10}{|c|}{ Обсяги прямих іноземних інвестиції } & \multirow{3}{*}{$\begin{array}{c}\text { Темп } \\
\text { приросту } \\
(2014 / 2010 \\
\text { pp.) } \\
\%\end{array}$} \\
\hline & \multicolumn{2}{|c|}{2010 p. } & \multicolumn{2}{|c|}{2011 p. } & \multicolumn{2}{|c|}{2012 p. } & \multicolumn{2}{|c|}{2013 p. } & \multicolumn{2}{|c|}{2014 p. } & \\
\hline & $\begin{array}{l}\text { млн. } \\
\text { дол. }\end{array}$ & $\%$ & $\begin{array}{l}\text { млн. } \\
\text { дол. }\end{array}$ & $\%$ & $\begin{array}{l}\text { млн. } \\
\text { дол. }\end{array}$ & $\%$ & $\begin{array}{l}\text { млн. } \\
\text { дол. }\end{array}$ & $\%$ & $\begin{array}{l}\text { млн. } \\
\text { дол. }\end{array}$ & $\%$ & \\
\hline 1 & 2 & 3 & 4 & 5 & 6 & 7 & 8 & 9 & 10 & 11 & 12 \\
\hline Кіпр & 9914,6 & 22 & 12645,5 & 26 & 17275,1 & 32 & 19035,9 & 33 & 13710,6 & 30 & 38,3 \\
\hline Німеччина & 7076,9 & 16 & 7386,4 & 15 & 6317 & 12 & 6291,8 & 11 & 5720,5 & 13 & $-19,2$ \\
\hline Нідерланди & 4707,8 & 11 & 4822,8 & 10 & 5168,6 & 10 & 5561,5 & 10 & 5111,5 & 11 & 8,6 \\
\hline $\begin{array}{l}\text { Російська } \\
\text { Федерація }\end{array}$ & 3402,8 & 8 & 3594,5 & 7 & 3785,8 & 7 & 4287,4 & 7 & 2724,3 & 6 & $-19,9$ \\
\hline Австрія & 2658,2 & 6 & 3423,1 & 7 & 3401,4 & 6 & 3257,5 & 6 & 2526,4 & 6 & -5 \\
\hline $\begin{array}{l}\text { Велика } \\
\text { Британія }\end{array}$ & 2298,8 & 5 & 2508,2 & 5 & 2556,5 & 5 & 2714,1 & 5 & 2145,5 & 5 & $-6,7$ \\
\hline $\begin{array}{l}\text { Віргінські } \\
\text { острови }\end{array}$ & 1460,8 & 3 & 1607 & 3 & 1884,9 & 4 & 2498,5 & 4 & 1997,7 & 4 & 36,8 \\
\hline
\end{tabular}


Продовження табл. 2

\begin{tabular}{|l|c|c|c|c|c|c|c|c|c|c|c|}
\hline \multicolumn{1}{|c|}{1} & 2 & 3 & 4 & 5 & 6 & 7 & 8 & 9 & 10 & 11 & 12 \\
\hline Франція & 2367,1 & 5 & 2230,7 & 5 & 1765,3 & 3 & 1825,8 & 3 & 1614,7 & 4 & $-31,8$ \\
\hline Швейцарія & 859,4 & 2 & 960,3 & 2 & 1106,2 & 2 & 1325,4 & 2 & 1390,6 & 3 & 61,8 \\
\hline Італія & 982,4 & 2 & 965,9 & 2 & 1015,9 & 2 & 1267,8 & 2 & 999,1 & 2 & 1,7 \\
\hline США & 1192,4 & 3 & 1043,1 & 2 & 936,7 & 2 & 991,1 & 2 & 862,3 & 2 & $-27,7$ \\
\hline Польща & 935,8 & 2 & 875,5 & 2 & 916,4 & 2 & 845,4 & 1,5 & 831,2 & 2 & $-11,2$ \\
\hline Інші країни & 6851 & 15 & 7299,3 & 14 & 8332,6 & 15 & 8259,7 & 14 & 6281,6 & 14 & $-8,3$ \\
\hline Разом & 44708 & 100 & 49362,3 & 100 & 54462,4 & 100 & 58161,9 & 100 & 45916 & 100 & 2,7 \\
\hline
\end{tabular}

Джерело: розраховано авторами за [13]

Сукупний обсяг залучених прямих іноземних інвестицій в економіку України на 31 грудня 2014 р. становив 45916,0 млн. дол. (у розрахунку на одну особу - 1072,0 дол.) [13]. За період 2010-2013 рр. спостерігається тенденція до зростання обсягу надходження іноземного капіталу на $30 \%$ (на 13448,9 млн. дол.), проте у 2014 р. інвестиційні надходження скоротилася на $21 \%$ у порівнянні 32013 р. (на 12240,9 млн. дол.), що стало наслідком погіршенням інвестиційного клімату в державі загалом через інфляцію, політичну та економічну нестабільність.

У 2014 р. інвестиції в Україну надійшли зі 131 країни світу, зокрема країнами $\mathrm{CC}$ інвестовано 77,5\% загального обсягу акціонерного капіталу (35575,5 млн. дол.), з інших країн світу - 22,5\% (10340,5 млн. дол.) [13]. Інвестиційні надходження в економіку України за країнами походження у 2014 р представлені на рис. 1.

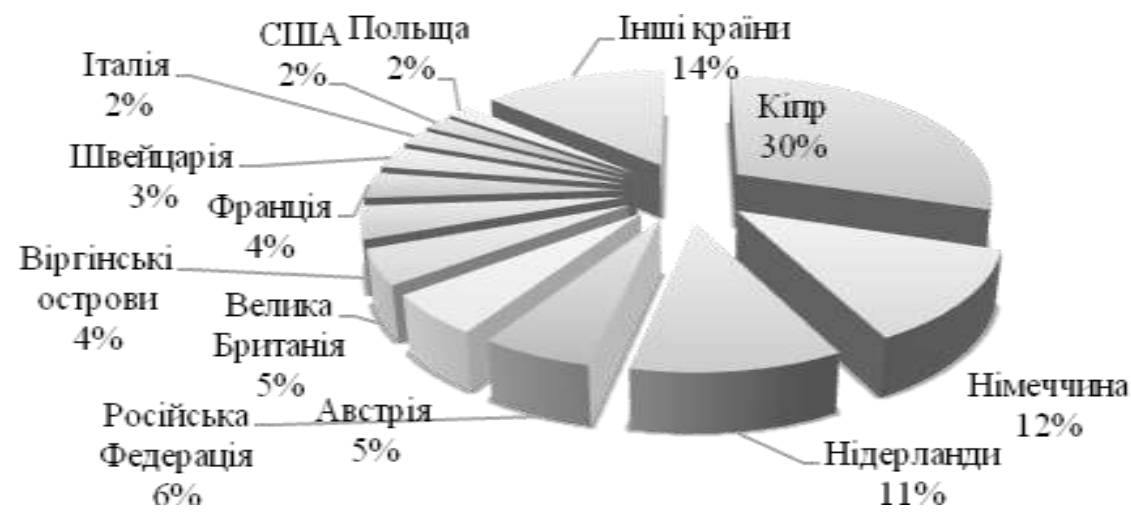

Рис. 1. Інвестиційні надходження в економіку України за країнами походження у 2014 р., \% [13]

Аналіз галузевої структури прямих іноземних інвестицій свідчить, що у 2014 р. майже третина їх спрямована у промисловість (32,3\%), проте в основному фінансуються низькотехнологічні галузі виробництва (переробна 
промисловость - 27,4\%), в установах фінансової та страхової діяльності зосереджено 25,1\% іноземного капіталу, на підприємствах оптової та роздрібної торгівлі - 13,1\%. Менш привабливими видами економічної діяльності $є$ операції 3 нерухомим майном - 8,3\%, наукова та технічна діяльності - 6,2\%, сільське господарство - 1,3\%. Протягом досліджуваного періоду скоротилося інвестування сільськогосподарського комплексу (на $17,4 \%$ ) та фінансових установ (на 22,8\%), проте зросли обсяги надходжень у промислові підприємства (на 9,5\%), підприємства оптової торгівлі (на 28\%), у будівництво (на 16,1\%), професійну наукову та технічну діяльність (у 2,5 рази), операції з нерухомим майном (на 24,9\%) [13].

У регіональному розрізі у 2014 р. 93,7\% загального обсягу інвестицій спрямовано у Дніпропетровську, Донецьку, Харківську, Київську, Одеську, Львівську області та м. Київ [13]. Зазначений регіональний розподіл коштів зумовлює нерівномірний соціально-економічний розвиток регіонів, оскільки відсутність грошових потоків до виробничих суб'єктів в периферії зменшує відповідні надходження до місцевих бюджетів.

3 огляду на наявні тенденції іноземного інвестування проаналізуємо інвестиційний клімат України, шляхом дослідження позицій країни у міжнародних рейтингах (табл. 3).

Таблиця 3

\section{Місце України у світових рейтингах}

\begin{tabular}{|c|c|c|c|c|c|}
\hline \multirow{2}{*}{ Рейтинг } & \multirow{2}{*}{2010 p. } & \multirow{2}{*}{2014 p. } & \multirow{2}{*}{2015 p. } & \multicolumn{2}{|c|}{$\begin{array}{c}\text { Абсолютне відхилення } \\
\text { рейтингу }\end{array}$} \\
\hline & & & & $\begin{array}{l}\text { 2014-2010 } \\
\text { pp. }\end{array}$ & $\begin{array}{l}\text { 2015-2014 } \\
\text { pp. }\end{array}$ \\
\hline The Global Competitiveness Index & 89 & 76 & 79 & -13 & +3 \\
\hline International Business Compass & - & 109 & 89 & - & -20 \\
\hline Doing Business & 142 & 112 & 96 & -30 & -16 \\
\hline Investment Attractiveness Index & 3,28 & 2,5 & 2,57 & $-0,78$ & $+0,07$ \\
\hline FDI Index & 0,144 & 0,142 & 0,12 & $-0,02$ & $-0,022$ \\
\hline Index of Economic Freedom & 162 & 155 & 162 & -7 & +7 \\
\hline
\end{tabular}

Джерело: розраховано авторами за $[14,15,16,17,18,19]$

За Індексом конкурентоспроможності у 2014 р. Україна піднялася на 13 позицій в порівнянні з базовим період, проте у 2015 р. втратила 3 позиції (через незадовільні показники складових макроекономічного середовища та слабкий рівень розвитку фінансового ринку). За Індексом інвестиційної привабливості у 2015 р. країна зайняла 89 місце із 174 країн (покращила свій показник на 20 позицій). У рейтингу Doing Business у 2014 р. піднялася на 112 місце із 142, а у 2015 р. зайняла 96 місце (покращила свої позиції на 16 пунктів за рахунок прогресу у сферах реєстрації прав власності та 
оподаткування). За оцінкою ЄБА, найбільш інвестиційно привабливою Україна була у 2010 р. - 3,28 бали з 5, у 2014 р. значення скоротилося до 2,5. За Індексом прямих іноземних інвестицій Україна покращила позиції із 0,144 у 2010 р. до 0,12 у 2015 р., проте економіка країни є недостатньо відкритою для надходження прямих іноземних інвестицій, оскільки значення індексу на 66\% перевищує показник Польщі, на 23\% - показник США та на 13\% показник Австрії [18]. За рейтингом Індексу економічних свобод Україна у 2014 р. посіла 155 місце серед 186 країн, проте у 2015 р. опустилася на 162 позицію.

Низькі позиції України в досліджуваних рейтингах свідчать про ризиковий інвестиційний клімат та є наслідком погіршення макроекономічних показників, що зумовило від'ємний приріст інвестиційних надходжень (-21\%) у поточному періоді. Найбільш проблемними факторами ведення бізнесу є: високий рівень корупції, ускладнений доступ до фінансів, інфляція, політична нестабільність, високі податкові ставки та недосконале податкове законодавство, державна бюрократія. Зазначені чинники обмежують приплив іноземного капіталу та зумовлюють дефіцит фінансових ресурсів, наслідком чого є соціально-економічний спад та криза.

Разом із наявними дестабілізуючими факторами вітчизняного бізнессередовища, слід зазначити, що Україна володіє потужним інвестиційним потенціалом, проте для його активізації необхідно здійснити ряд заходів щодо зміни інвестиційної політики влади, поліпшення загального бізнес-клімату та режимів конкуренції. У зазначених напрямках державою вже здійснено ряд позитивних кроків, таких як [20]:

1. Створено правове поле для інвестування та розвитку державноприватного партнерства: законодавство України визначає гарантії діяльності для інвесторів, економічні та організаційні засади державно-приватного партнерства в Україні.

2. Застосування національного режиму інвестиційної діяльності для іноземних інвесторів та відсутність націоналізації іноземних інвестицій.

3. Ратифікація Вашингтонської Конвенції про порядок вирішення інвестиційних спорів між державами та іноземними особами та міжурядових угод про сприяння та взаємний захист інвестицій з 70 країнами світу (зокрема 05.02.2015 р. підписано Угоду між Україною та Японією).

4. Визначено перелік видів господарської діяльності та відмінено ліцензування 26 типів господарської діяльності; скасовано неефективну сертифікацію в сільськогосподарській сфері.

5. Забезпечено адаптацію українського законодавства до загальноєвропейського та запущено в публічний доступ модуль бізнесаналітики, який надає громадянам онлайн-доступ до інформації про закупівлі. 
6. Державна підтримка при створенні індустріальних парків та реалізації проектів у їх межах.

7. Проведено українсько-американський бізнес-форуму (13 липня 2015 р.), під час якого укладено угоди 3 компанією Cargill щодо започаткування інвестиційного проекту з розвитку інфраструктури морського порту «Южний» (обсяг інвестицій - 130 млн. дол.) та 3 компанією Horizon Capital щодо інвестиції в інтернет-магазин Rozetka.ua (до 40 млн. дол.).

Однак, перерахованих кроків недостатньо для створення якісно нових умов ведення бізнесу та активізації інвестиційної діяльності. Для підвищення дієздатності механізмів забезпечення інвестиційного клімату та нарощування конкурентоспроможності вітчизняної економіки необхідно здійснити низку першочергових заходів, таких як:

- здійснити раціональний галузевий та регіональний розподіл іноземних надходжень для рівномірного економічного розвитку регіонів та галузей економіки;

- забезпечити усунення бар'єрів для інвестування у сфері АПК, оскільки за прогнозом СБРР більше 20 міжнародних компаній протягом найближчих трьох років готові вкласти в аграрний сектор України до $€ 2,5$ млрд. [21, с. 33];

- удосконалити механізми державно-приватного партнерства, спрямовані на впровадження програм спільного фінансування проектів, зокрема у сфері логістики АПК: модернізація транспортної інфраструктури (залізничного та річкового транспорту) та розвиток інфраструктури по зберіганню продукції, створення переробних підприємств 3 міжнародною сертифікацією;

- надати законодавчу підтримку для створення спільних підприємств за китайською схемою, яка передбачає володіння контрольним пакетом акцій підприємства українською стороною, а через 5-7 років українськими мають бути 75\% акцій, і ще через 10-12 років спільне підприємство повністю стає українським [3];

- підтримка необхідного рівня соціального забезпечення, державної допомоги та зайнятості населення як чинників, що сприяють покращенню бізнес-середовищу.

Отже, слід зазначити, що реалізація зазначених заходів сприятиме підвищенню інвестиційної привабливості вітчизняної економіки та активізації невикористаного інвестиційного потенціалу, що в перспективі призведе до стабілізації та розвитку економіки України.

Висновки. Проведене дослідження інвестиційних процесів в економіці України надало можливість відзначити, що прямі іноземні інвестиції $€$ вагомим чинником, який впливає на темпи економічного зростання та розвиток країни в цілому, оскільки $є$ передумовою розширення міжнародного співробітництва та створення соціального ефекту у вигляді зростання доходів 
населення. Виявлено, що скорочення надходжень іноземного капіталу у 2014 р. на 21\%, обумовлено несприятливим інвестиційним кліматом, що викликано низкою причин, а саме: політичною й економічною нестабільністю, недосконалістю митної, фіскальної політики, нерозвиненістю інвестиційної й логістичної інфраструктури. Для соціально-економічного розвитку та технологічної модернізації України необхідно активізувати ii наявний інвестиційний потенціал шляхом створення сприятливих умов інвестування. Для цього державі необхідно здійснити ряд заходів щодо зміни інвестиційної політики, поліпшення загального бізнес-клімату та режимів конкуренції.

Науковою новизною дослідження $є$ ідентифікація пріоритетних заходів щодо підвищення інвестиційного клімату України та зростання надходжень іноземного капіталу для розвитку вітчизняної економіки.

Перспективами подальших наукових досліджень може бути розробка стратегії залучення іноземного капіталу у розвиток АПК України з метою розвитку національної економіки та розширення міжнародного співробітництва.

\section{Лiтература:}

1. Кадеєва I. В. Прямі іноземні інвестиції як фактор становлення інноваційної економіки в Україні / І. В. Кадеєва // Збірник наукових праць Харківського національного педагогічного університету імені Г. С. Сковороди. Економіка. - 2014. - Вип. 14. - С. 193-199.

2. Коваленко О. В., Тимофєєва К. Пріоритетні напрямки іноземного інвестування в Україні [Електронний ресурс] Запорізька державна інженерна академія. - Режим доступу: http://www.zgia.zp.ua/gazeta/evzdia_1_078.pdf.

3. Кудрик Г. П. Роль іноземних інвестицій у фінансуванні інноваційного процесу в Україні [Електронний ресурс] Інтелект-портал. - Режим доступу: http://nauka.zinet.info/1/kudrik.php.

4. Леус М. М. Суть та класифікація іноземних інвестицій [Електронний ресурс] Видавництво Львівської Політехніки. - Режим доступу: http://vlp.com.ua/files/27_17.pdf.

5. Реверчук С. К. Інвестологія: наука про інвестування: [Навч. посібник] / С. К. Реверчук , Н. Й. Реверчук, І. Г. Скоморович [та ін. ]. - Атіка, 2001. - 264 с.

6. Рогач О. I. Міжнародні інвестиції: Теорія та практика бізнесу трнснаціональних корпорацій: [Підручник] / О. І. Рогач. - К.: Либідь, 2005. - 720 с.

7. Петренко I. С. Інвестиції зовнішньоекономічної діяльності України [Статистичний збірник] / І. С. Петренко. - Державна служба статистики України, 2015 р.

8. Тесля С. М. Прямі іноземні інвестиції як економічна категорія, їх суть та класифікація / С. М. Тесля // Науковий вісник НЛТУ України. - 2009. - Вип. 19.3. - С. 131-139.

8. Про режим іноземного інвестування: Закон України від 19.03.1996 р. №93/96: за станом на 15.01.2011 р. // Відомості Верховної Ради України. - 1996. - № 93. - Ст. 80.

10. Hymer, Stephen H. The International Operations of National Firms: A Study of Direct Foreign Investment / Hymer, Stephen H. - (MIT Press), 1976. - 253 c.

11. Trade and Investment [Електронний pecypc] World Trade Organization. - Режим доступу: https://www.wto.org/english/tratop_e/invest_e/invest_e.htm. 
12. Балацький О. Ф., Теліженко О. М., Соколов М. О. Управління інвестиціями: [Навч. посібник] / О. Ф. Балацький, О. М. Теліженко, М. О. Соколов. - С.: ВДТ «Університетська книга», 2004. - 232 с.

13. Зовнішньоекономічна діяльність [Електронний ресурс] Державна служба статистики України. - Режим доступу: http://www.ukrstat.gov.ua.

14. України в рейтингу глобальної конкурентоспроможності - 2015 [Електронний ресурс] Рада реформ. - Режим доступу: http://reforms.in.ua/ua/news/ukrayina-u-reytynguglobalnoyi-konkurentospromozhnosti-2015.

15. The BDO International Business Compass 2015: Update and Subject Focus Labor Market Performance [Електронний pecypc] BDO International. - Режим доступу: http://www.bdointernational.com/Publications/Documents/BDO-IBC-Summary2015_ENG_v1_May\%202015.pdf.

16. Doing Business-2015 [Електронний ресурс] Група Світового Банку. - Режим доступу: http://russian.doingbusiness.org/rankings.

17. Індекс інвестиційної привабливості України [Електронний ресурс] EBA. - Режим доступу: http://www.eba.com.ua/uk/information-support/eba-news/important/item/31670 2015-4-15-1053.

18. Індекс прямих іноземних інвестицій [Електронний ресурс] OECD. - Режим доступу: https://stats.oecd.org/Index.aspx?DataSetCode=FDIINDEX.

19. Index of economic freedom [Електронний ресурс] The Heritage Foundation. - Режим доступу: http://www.heritage.org/index/country/ukraine.

20. Інвестиційний клімат в Україні [Електронний ресурс] Міністерство закордонних справ України. - Режим доступу: http://mfa.gov.ua/ua/about-ukraine/economic-cooperation/investclimat. 